\title{
MODERN ELECTRIC CARS OF TESLA MOTORS COMPANY
}

\author{
O. F. Vynakov, Ph.D. in technical sciences, associate professor ${ }^{1}$, E.V. Savolova, senior lecturer ${ }^{2}$, A.I. Skrynnyk, \\ student $^{3}$ \\ 1,2,3 Odessa National Polytechnic University, Odessa \\ ${ }^{2}$ Odessa National Academy of Food technologies, Odessa
}

E. mails: ${ }^{1}$ afvinakov@gmail.com,${ }^{2}$ elvira_onaxt@mail.ua,${ }^{3}$ anton_dora@mail.ru

${ }^{1}$ ORCID: 0000-0002-6630-8986

${ }^{2}$ ORCID: 0000-0001-9266-9323

Copyright (C 2014 by author and the journal "Automation technological and business - processes". This work is licensed under the Creative Commons Attribution International License (CC BY). http://creativecommons.org/licenses/by/4.0/

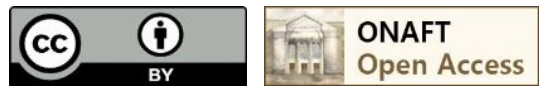

DOI: $10.15673 /$

\begin{abstract}
This overview article shows the advantages of a modern electric car as compared with internal combustion cars by the example of the electric vehicles of Tesla Motors Company. It (в смысле- статья) describes the history of this firm, provides technical and tactical characteristics of three modifications of electric vehicles produced by Tesla Motors. Modern electric cars are not less powerful than cars with combustion engines both in speed and acceleration amount. They are reliable, economical and safe in operation. With every year the maximum range of an electric car is increasing and its battery charging time is decreasing.

Solving the problem of environmental safety, the governments of most countries are trying to encourage people to switch to electric cars by creating subsidy programs, lending and abolition of taxation. Therefore, the advent of an electric vehicle in all major cities of the world is inevitable.
\end{abstract}

Key words

Electric vehicles, company Tesla Motors, Tesla Roadster, Tesla Model S, Tesla Model X.

Nowadays, in the era of supersonic speeds and high technologies, when (and it's not a secret) people managed by their reckless and short-sighted activities to bring their life environment to a critical state, the issues related to environmental protection and careful attitude to the use of natural resources ceased to be simply " buzzwords " used to keep up a conversation. They have become government policy issues and our survival and further existence of the human race on the Planet directly depend on their competent and successful solution.

The essential component of ecological safety is the problem of environmental safety of vehicles, the urgency and importance of which is growing annually with the increasing number of vehicles. In the 1980s the number of private vehicles has become extraordinarily high, which led to the formation of smoggy bowls over the metropolis.

All of the available environmental protection organizations started sounding an alarm about the pollution, which had become global. US became a leader by pollution levels in some areas, namely, California in the early 1990s was one of the most polluted. Cars produce up to $70 \%$ of harmful emissions into the atmosphere; the amount of emissions per year in the world is about 22 million tons of pollutants of different origin: oxide and carbon dioxide, nitrogen oxides, hydrocarbons, lead compounds, sulphur, particulate pollutants, aldehydes, carcinogens. On average, they are increasing by $3.1 \%$ every year $[1,2$, 3].

Absorbing oxygen, a vehicle emits intensively toxic components into the air, which leads to growth of annual environmental damage. Automobile transport, polluting the biosphere with products of automobile fuel combustion, is a source of emissions into the environment a complex mixture of chemical compounds, the composition of which depends on the engine type, fuel type and vehicle operating conditions. Once in the atmosphere, as a result of chemical reactions with other air pollutants, they form even more hazardous compounds affecting ruinously the ecosystem. 
Vehicle emission, when getting onto the Earth surface in drainage basins, into open water, underground water, leads to the contamination of water bodies. Dust and dirt carried by vehicles contains more than 200 types of chemical of substances, many of which are radioactive. The dust deposits in the lungs and dissolves in the human blood, accumulates in the body, causing diseases of various organs, cancer, allergies [4].

The noise impact of vehicles is also unsafe for humans: a person loses a large amount of energy, it increases aggressiveness, develops hypertension, deteriorating hearing, reduces life expectancy [1].

Due to the growth of traffic flow, the number and power of electric equipment in each separate vehicle, the level of electromagnetic pollution increase [5].The human central nervous system, immune system, eyes, gonads (endocrine glands of genital organs) are the most sensitive to the electromagnetic emission. Herewith, power is less harmful than the duration of the radiation [6].

But there is currently no alternative to automobile transport, that could be more convenient, affordable in price-to-quality ratio and more popular in all spheres of activity. Moreover, it can [2]:

- provide fast and timely delivery of goods and passengers in small quantities;

- deliver goods directly to the consumer;

- is characterized by enhanced maneuverability, mobility and convenience of driving.

All of the aforesaid have led to the need to create and develop new types of car, which would primarily be more environmentally friendly and less costly. Perhaps, it would be an electric car, a vehicle driven by an electric motor instead of an internal combustion engine (ICE), which has no gearbox, due to the attachment of a shaft directly to wheels. It can be charged from both specialized charging stations, and from a home electric outlet.

In 1998, the California Air Resources Board (CARB) adopted the decision which indicated the number of cars with zero exhaust, sold per year. In the same 1998 year, this percentage was 2\%, and by 2003 it has come to over $10 \%$. The EU governments announced the transition to electric vehicles during the period of 2015 - 2020 and reinforced this decision, on the one hand, by imposing a substantial fines for excess of CO2 emissions by new vehicles, produced in the EU in 2015 , for the rate of 130 grams per kilometer, and by 2020 for the rate of $95 \mathrm{~g}$ of CO2 per kilometer (up to 95 Euros for each gram exceeding the norm), and, on the other hand, to get "super credits" on the production of "clean" cars until 2016.

According to conventional opinion, the advantage of an electric car, compared with conventional vehicle, is its environmental friendliness, since it does not use combustible mixtures, and thus causes no harmful emissions into the atmosphere and the explosiveness considerably reduces. The energy used in electric vehicles today is definitely cheaper than gasoline and diesel fuel. The batteries of such vehicles can be charged during the slope movement (recovery mode) or from sunlight. Easy assembly and simple design provide reliability and service life of an electric vehicle, expand service interval mileage, resulting in significant cost savings for the owner. Low noise level assures comfort [7].

But this car is not without shortcomings too, which include the production difficulties of cheap (precious metals are currently used to create them) and capacious battery packs for a long-term work, free from harmful substances, which creates a problem of their disposal. The problem is also the relatively low mileage between the battery chargings [2], which decreases if the ambient temperature goes down. The temporary disadvantage is the absence of advanced electric transport infrastructure (network of electric charging stations and service stations, etc.).

The elimination of these shortcomings will lead to a significant increase in the number of electric vehicles in the developed countries. In the XXI century, electric cars are confidently winning the automobile manufacturing markets of the USA, Europe and Asia. Tesla Motors is rightfully considered to be one of the leaders in production of electric automobiles, as evidenced by the report data for the first half of 2015, published by the Internet community of EV Sales. The company ranks second in the number of sold electric cars (21.6 thousand hatchbacks of Model S), being ahead of the world leader Nissan (25,000 Nissan Leaf) in sales in the USA - [8].

Such rapid development of the company has been provided not only due to the name of the most mysterious, and prominent inventor Nicola Tesla and huge financial investment, but also due to the competent innovation policy in creating and promoting their electric vehicles in the global market with a long-term strategic goal to create affordable costs of electric vehicles:

- explicit target of operation sector to produce an electric vehicle, while the competitors were experimenting with hybrid cars, which became according to the company (as FEP technology almost completely depleted the possibilities of modernization and improvement) a restraint in the development;

- in-house design and manufacturing of the main units (battery pack, its cooling system, engine, electronics, charger,...), as well as their operational software;

- prompt infrastructure creation of charging and service stations its own electric vehicles;

- refusal from dealers services (sale of automobiles is carried out without engaging any local dealers centers);

- implementation of new technologies, both in the production process (90\% automation), and the vehicle driving process (management and control of all key functions via software);

- openness (Tesla Motors has opened its patent portfolio for public use to promote their technologies and standards) $[9,10]$. 
The company was established in 2003 by Martin Eberhard, Marc Tarpenning, Jeffrey B. Straubel and Ian Wright . In the first major sale of shares a successful businessman Elon Musk joined it as a Chairman of the Board in February 2004.

Elon Musk wanted to demonstrate to the whole world that beautiful, dynamic electric vehicles with a large range on one battery charge are not a fiction.

The presentation of high-class electric vehicle (fashionable, stylish and cutting edge kitsch) was necessary for the rapid development from zero level and entry to the world consumer market. Therefore, the first model has become a two-seater electric sports car Tesla Roadster, introduced in August 2006, which design was borrowed from another, more famous model Lotus Elise. However, all the components were developed by the company staff with Elon Musk taking part in designing of each element.

To start up mass production of Tesla Roadster initially scheduled for September 2007, Tesla Motors had been continuously looking for new investors, including Compass Technology Partners, SDL Ventures, Valor Equity Partners, cofounders of Google Sergey Brin and Larry Page, the former president of eBay, Jeffrey Skoll and others. The amount of investment in Tesla Motors by 2007 has exceeded $\$ 105$ million, and by the time the first production version left the assembly line in 2008, has reached \$ 140 million (instead of the planned \$ 25 million). In early August 2009, the company announced the overall profitability for the month of July and making a profit of 1 million dollars, and 4 years later in May 2013 the company was the first and the only one of the automobile companies to repay a loan of 465 million dollars, obtained from the US Department of Energy [11, 12 ].

Currently, the vehicle line of the electric car manufacturer consists of three different not only in their appearance, but by function and purpose cars: sport car Tesla Roadster, hatchback Tesla, Model the S, crossover Tesla Model X.

By the technical characteristics two versions of a sports car can be distinguished: Tesla Roadster (2008) and Tesla Roadster Sport (2009). The electric vehicle is driven by three-phase four-pole electric motor. Thrust is transmitted to the wheels of the rear axle via a single-stage transmission developed by BorgWarner Company. Upgrading concerned the engine, increasing the torque and acceleration time of $0.2 \mathrm{~s}$ (see Table 1). In the passenger compartment of Tesla Roadster Sport the aluminum gearbox lever gave way to key operated mechanism; the color touch screen appeared on the center console, and high-quality leather and carbon fiber insertions were used in the interior trim.

Table 1 - Technical specifications of Tesla Roadster (2008 - 2012)

\begin{tabular}{|c|c|c|}
\hline Automobile & \multicolumn{2}{|c|}{ Tesla Roadster } \\
\hline Modification type & Electro AT (185 kW) & Sport Electro AT (215kW) \\
\hline Body type & \multicolumn{2}{|c|}{ Roadster } \\
\hline Number of seats & \multicolumn{2}{|c|}{2} \\
\hline Length, mm & \multicolumn{2}{|c|}{3946} \\
\hline Width, mm & \multicolumn{2}{|c|}{1851} \\
\hline Height, mm & \multicolumn{2}{|c|}{1126} \\
\hline Wheel-base, mm & \multicolumn{2}{|c|}{2351} \\
\hline Kurb weight, kg & \multicolumn{2}{|c|}{1238} \\
\hline Rear electric traction motor & \multicolumn{2}{|c|}{ 3-phase, 4-pole asynchronous AC motor } \\
\hline Location & \multicolumn{2}{|c|}{ Transverse between rear wheels } \\
\hline Maximum power, hp. (kW / rpm & $\begin{array}{l}251(185) / 5000-8000 \\
\quad(14000 \max )\end{array}$ & $291(215) / 8500(14000 \max )$ \\
\hline Maximum torque, $\mathrm{Nm} / \mathrm{rpm}$ & $270 / 0-5400$ & $400 / 0-5100$ \\
\hline Traction battery accumulator (TBA) & $\begin{array}{c}\text { Lithium ion battery, } \\
\text { capacity } 37,4 \mathrm{~kW} \cdot \mathrm{h}(\text { voltage } \\
375 \mathrm{~V})\end{array}$ & $\begin{array}{l}\text { Lithium ion battery, capacity } \\
53 \mathrm{~kW} \cdot \mathrm{h} \text { (voltage } 375 \mathrm{~V})\end{array}$ \\
\hline Drive gear & rear & rear \\
\hline Drive train & \multicolumn{2}{|c|}{ variator } \\
\hline Tires & \multicolumn{2}{|c|}{ 175/55/R16 - 225/45/ R17 } \\
\hline Top speed, km/h & $201 *$ & $201 *$ \\
\hline Acceleration time $0-100 \mathrm{~km} / \mathrm{h}$ & 3,9 & 3,7 \\
\hline
\end{tabular}




\begin{tabular}{|l|l|}
\hline Maximum range, $\mathrm{km}$ (driving cycle NEDC) & \multicolumn{1}{|c|}{395} \\
\hline Remark & $*$ Limitation of electronics \\
\hline
\end{tabular}

In 2008, the German car tuning firm Brabus has presented an improved version of the Roadster, equipped with a "generator of ambient sound." In summer 2010, Tesla Motors submitted to production the updated version 2.5 (Fig. 1) with improved sound insulation, new bumper and chair design, new wheel discs, a seven-inch touch screen with navigation system and the ability to display images from a rear view camera, and 3.5 hours time of battery charging from a network with a voltage of 240 Volt.

However the technical characteristics of the improved models remained unchanged.

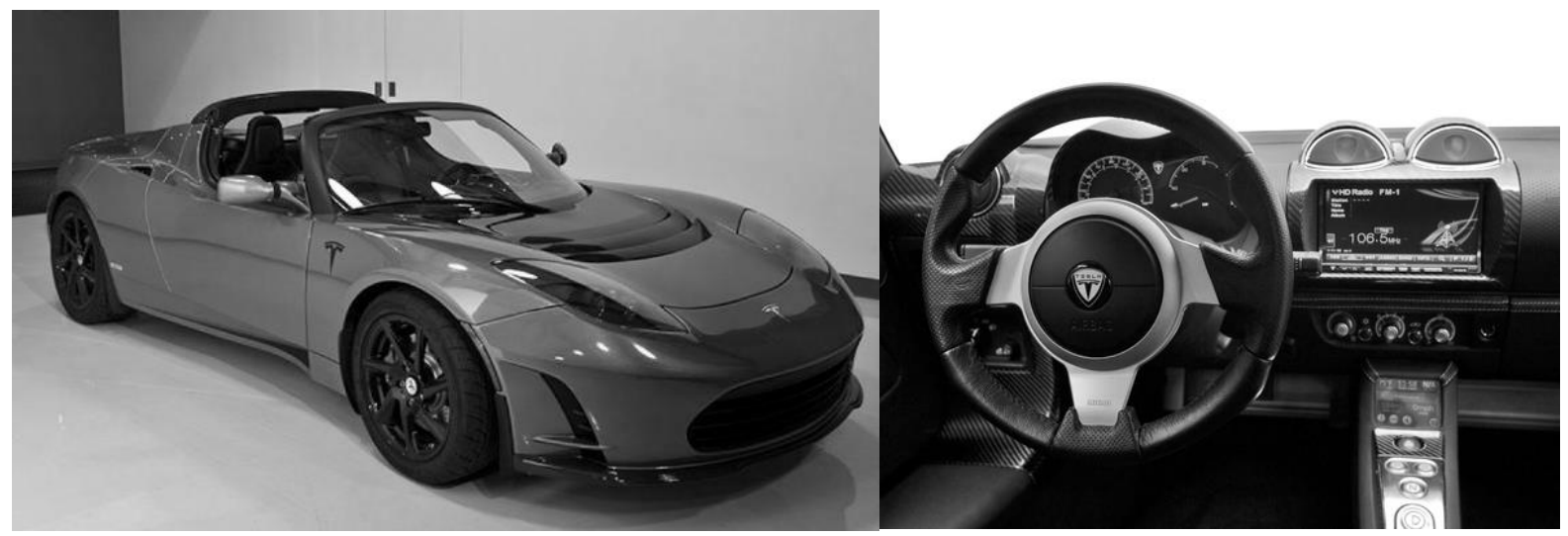

Fig. 1 - Model appearance and dashboard of Tesla Roadster 2.5 Sport

Tesla Roadster model release was completed in 2012, but already in late 2014 the manufacturer issued an update package, which received the designation 3.0. It encompassed: increased range up to 640 kilometers through installation of battery packs with new cells, capable of storing $31 \%$ more power than preceding counterparts; an aerodynamic body kit, providing a reduction in aerodynamic drag from 0.36 to 0.3 ; tires with reduced rolling resistance. At the same time, in spite of the increased capacity, the size of the battery pack (its capacity is $70 \mathrm{~kW} \cdot \mathrm{h}$ ) remained unchanged $[13,14,15]$.

The second model of the Tesla Motors electric car was the Tesla Model S (Fig. 2), presented by company in 2009 and subsequently recognized (according to the «Motor Trend» magazine, the USA) as the "Car of the Year 2013". In the USA, the first deliveries of Tesla Model S were launched in June 2012, in Europe - in August 2013 and in 2014 they started to be supplied to China.

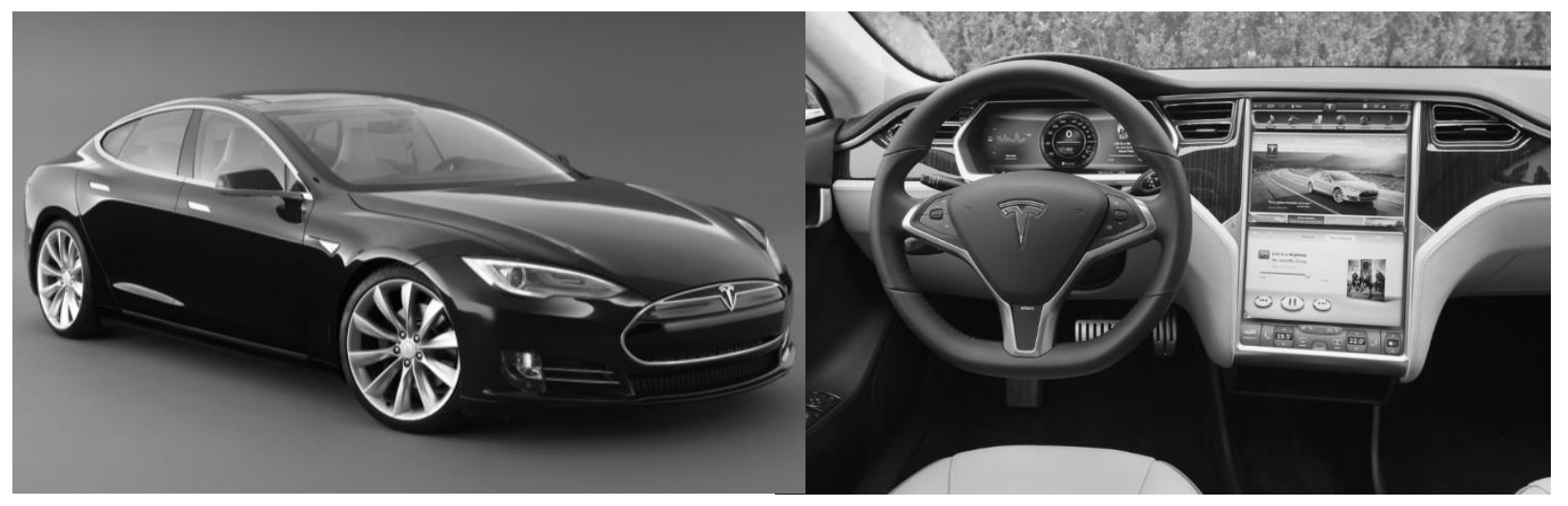

Fig. 2 - Model appearance and dashboard of Tesla Model S

Originally model lineup S consisted of rear-wheel drive Model S 60 (with a battery capacity of $60 \mathrm{~kW} \cdot \mathrm{h}$, an engine capacity of $306 \mathrm{hp}$, acceleration time up to $100 \mathrm{~km} / \mathrm{h}$ of 6.2 seconds, "ideal " range of $390 \mathrm{~km}$ ), S 85 (with a battery capacity of $85 \mathrm{~kW} \cdot \mathrm{h}$, engine capacity of $367 \mathrm{hp}$, acceleration time up to $100 \mathrm{~km} / \mathrm{h}-5.6$ seconds, the "ideal" range of $502 \mathrm{~km}$ ) and $\mathrm{S}$ P85.

Since 2014 Model S 60 has been equipped with the same engine as the S 85, and in 2015 it was replaced by two models S 70 (with a battery capacity of $70 \mathrm{~kW} \cdot \mathrm{h}$, engine capacity of $320 \mathrm{hp}$, acceleration time up to $100 \mathrm{~km} / \mathrm{h}-5.8 \mathrm{~s}$, the "ideal" range of $420 \mathrm{~km}$ ) and $\mathrm{s} 70 \mathrm{D}$ (with a battery capacity of $70 \mathrm{~kW} \cdot \mathrm{h}$, the two engines of $167 \mathrm{hp}$ each, the acceleration time to 100 $\mathrm{km} / \mathrm{h}-5.4$ seconds, the "ideal "reserve of $442 \mathrm{~km}$ ). At the same time a new Model S 85D (with two engines of $190 \mathrm{hp}$ each, the acceleration time up to $100 \mathrm{~km} / \mathrm{h}-5.4$ seconds, the "ideal" range of $502 \mathrm{~km}$ ) and the most advanced version of the P85D 
were introduced. Class letter «D» on new versions of Model S refers to the abbreviation Dual Motor (double motor). The second engine enables Model S P85D to drive at speeds up to $100 \mathrm{~km} / \mathrm{h}$ in just 3.2 seconds. Basic technical specifications for vehicles with a battery capacity of $85 \mathrm{~kW} \cdot \mathrm{h}$ are shown in the table below (see Table 2) $[16,17,18,19]$.

As of today, the basic configuration of Model S includes:

- heated front seats with electric settings to store the selected parameters;

- tail gate with electric drive;

- system of cabin access without a key;

- cruise control;

- climate control with 2 zones division;

- electric window lifters;

- automatically folding wing mirrors with electric drive and heating;

- 17-inch touch screen;

- interior background lighting with LEDs;

- 8 airbags;

- audio system with 7 speakers;

- regenerative braking system;

- additional anti-lock braking system ABS;

- Electronic Stability Control (ESC);

- Traction control system (TCS) and steering stiffness control;

- Leather interior;

- decorative elements of natural wood.

Expensive versions are equipped with air suspension, which allows changing road clearance in the range of 100 - 160 $\mathrm{mm}$, with a self-driving function, options of emergency braking and "dead zones" control.

For the Model S P85D the Tesla Company has developed the Ludicrous Mode option ("funny", "awkward"). It is designed to replace the fuse, protecting the battery, on a computerized, equipped with a microchip, own small lithium battery and pyrotechnic squib switch, which breaks the circuit in milliseconds in case of a dangerous current value. Moreover, inconel is used instead of steel in the battery contactor.

Replacement of the device allows you to raise permissible current strength in motors from 1300 to 1500 amperes. It increases traction and results in a reduction of acceleration time from zero to 60 miles / hour $(97 \mathrm{~km} / \mathrm{h})$ from 3.1 to 2.8 seconds.

Table 2 - Technical specifications of Tesla Model S (Performance)

\begin{tabular}{|c|c|c|c|}
\hline Automobile & \multicolumn{3}{|c|}{ Tesla Model S } \\
\hline Modification type & P85 & P85+ & P85D \\
\hline Body type & \multicolumn{3}{|c|}{ 5-two-door hatchback } \\
\hline Number of seats & \multicolumn{2}{|c|}{$5(7)$} & 5 \\
\hline Length, mm & \multicolumn{3}{|c|}{4970} \\
\hline Width, mm & \multicolumn{3}{|c|}{1964} \\
\hline Height, mm & \multicolumn{3}{|c|}{1445} \\
\hline Wheel-base, mm & \multicolumn{3}{|c|}{2960} \\
\hline Kurb weight, kg & 2108 & 2108 & 2262 \\
\hline Front electric traction motor & - & - & asynchronous AC motor \\
\hline Location & - & - & $\begin{array}{l}\text { Transverse, above } \\
\text { the front axle }\end{array}$ \\
\hline Maximum power, hp. $(\mathrm{kW}) / \mathrm{rpm}$ & - & - & $262(193) / 6100$ \\
\hline Maximum torque, $\mathrm{Nm} / \mathrm{rpm}$ & - & - & 331 \\
\hline Rear electric traction motor & \multicolumn{3}{|c|}{ asynchronous AC motor } \\
\hline Location & \multicolumn{3}{|c|}{ Transverse, above the rear axle } \\
\hline Maximum power, hp. $(\mathrm{kW}) / \mathrm{rpm}$ & $416(305) / 5000-8600$ & $422(310) / 5000-8600$ & $476(350) / 5950$ \\
\hline Maximum torque, $\mathrm{Nm} / \mathrm{rpm}$ & $600 / 0-5100$ & $600 / 0-5100$ & 600 \\
\hline
\end{tabular}




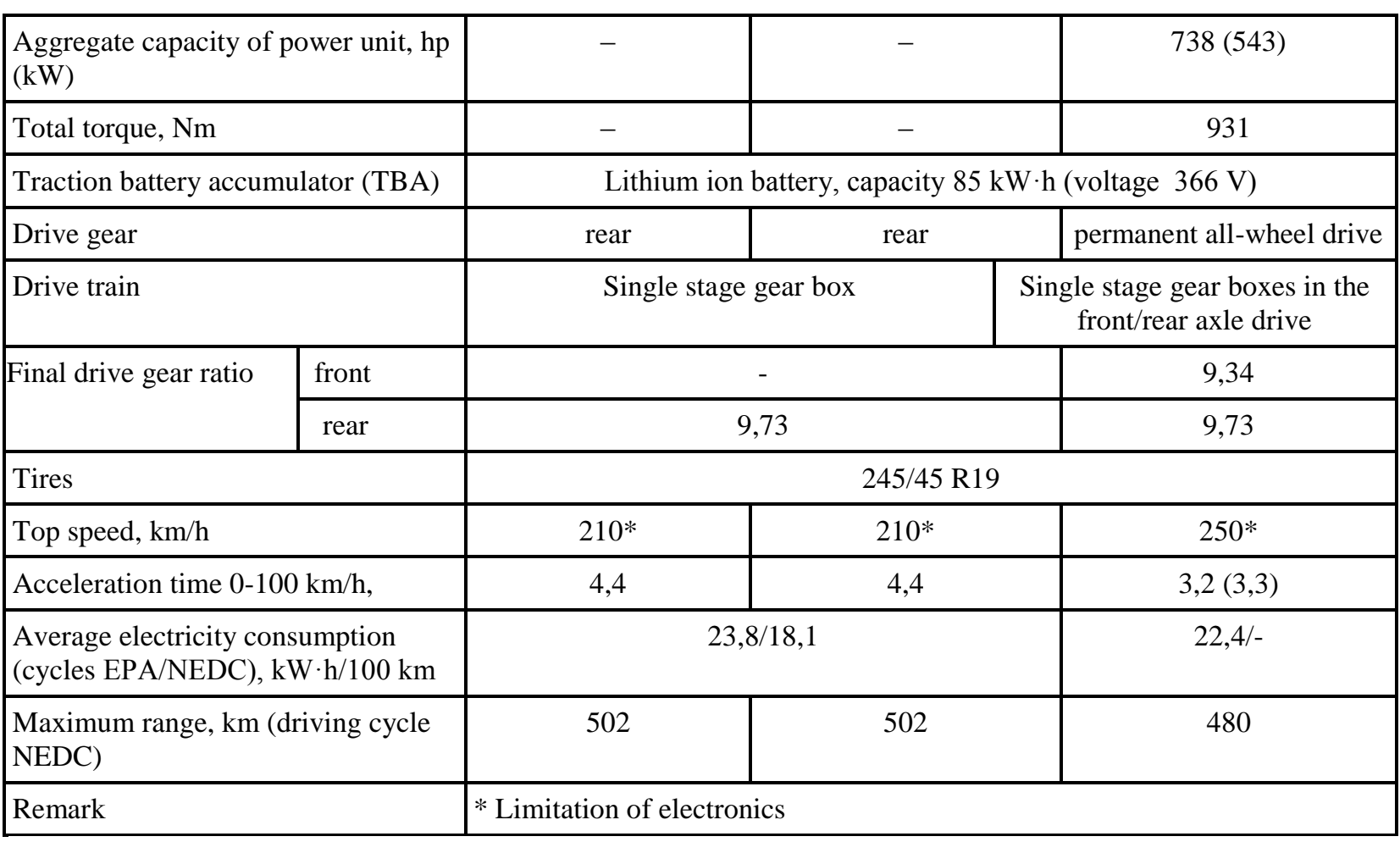

On September 29, 2015 in California, the official presentation of the family crossover Tesla Model X (Fig. 3) took place. Basic configuration of this model (in comparison with the Model S) was completed with [16, 20, 21, 22]:

- large wrap-around wind screen;

- three rows of seats $(2+2+2$ or $2+3+2)$ with adjustable backrest of the second seats row;

- the absence of intermediate clamps of the front door; front doors clamping mechanism,

- "Falcon wing" rear doors, providing convenient access to the third row of seats and facilitating the access to the passenger compartment in tight parking spaces (the required distance for door opening from the wall to electric crossover is $30 \mathrm{~cm}$ );

- sensors availability on all doors that virtually eliminates the possibility of damage, even in confined spaces;

- super-efficient air purification system of vehicle interior;

- availability of protection mode from the effects of biological weapons (!);

- Ludicrous option, allowing to reduce acceleration time to $100 \mathrm{~km} / \mathrm{h}$ from 3.8 seconds to 3.2 seconds;

- autopilot with automatic hold function specified on the highway corridor;

- automatically retractable carbon-fiber spoiler;

- air suspension with electronic storage of the road sections (using GPS);

- the eight-year unlimited mileage warranty and free servicing at all Supercharger stations.
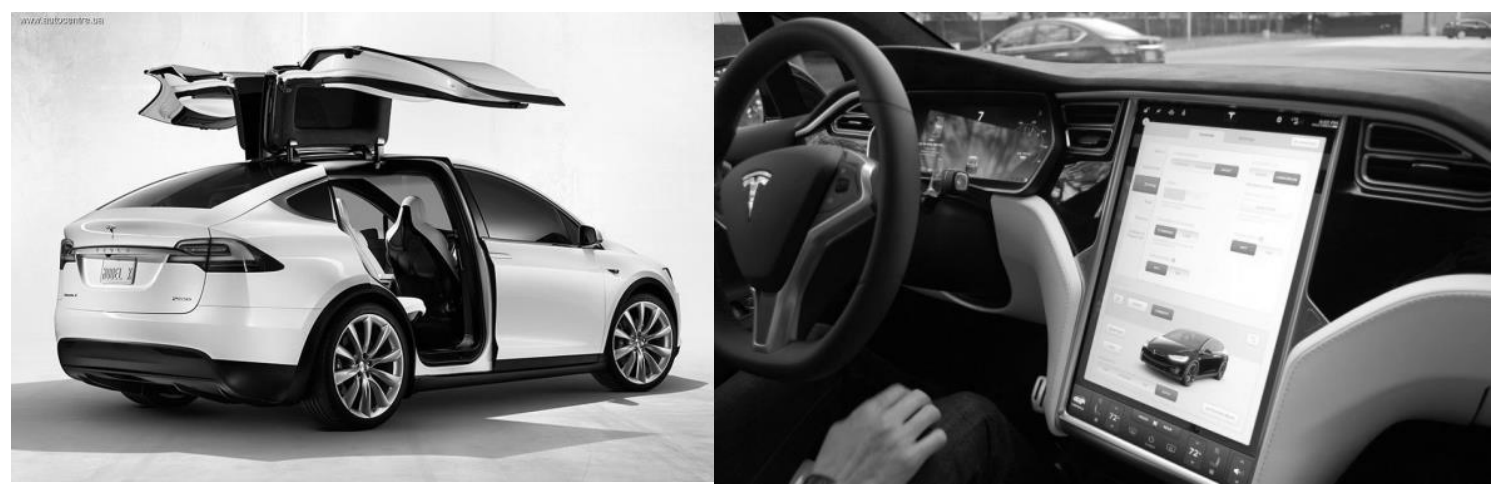

Fig. 3 - The model appearance and dashboard of Tesla Model X

The model comes in three versions, their currently known technical and tactical characteristics are summarized in the Table 3.

The standard charger (Mobile Connector) of single phase (US specification) or three-phase current (European specification) having the possibility to connect to a home electric outlet is supplied with each of the currently produced electric vehicle model. High power portable charging (High Power Wall Connector) is available for an extra fee. It is operable over a 
wide temperature range $(-35 \div+45){ }^{\circ} \mathrm{C}$. The charging speed in this case varies from 55 to 110 kilometers per charging hour (when connected to a home network of alternating voltage of $220 \mathrm{~V}-14 \mathrm{~km}$ per hour of charging) [20].

Accumulator unit of electric vehicle according to its creators consists of conventional lithium-ion batteries, but their connection scheme and the control system is obviously "know-how" in this branch of industry. The battery itself consists of 16 units located along the bottom of the car, and it increases considerably torsion stiffness and safety, due to lowering of center of gravity and to the perfect weight distribution between the axles.

Information and control system of the vehicle, based on the Ubuntu Linux operating system, is performed by two quadcore processors NVIDIA Tegra 3, one of which is responsible for operation of a group of digital measuring devices, the second one - entertainment information system with 17-inch $(43.18 \mathrm{~cm})$ touch display with a resolution of 1920 x 1080 .

The touch screen (Fig. 4) provides access to the functions of climate control, seats and windows heating, steering settings, audio / video devices, suspension, lighting, roof hatch or door locks, wireless connection to Google Maps, Pandora Music (Internet radio, where a user by entering the name of his favorite artist, can listen similar in style and sound composition), as well as all features of a real Internet browser.

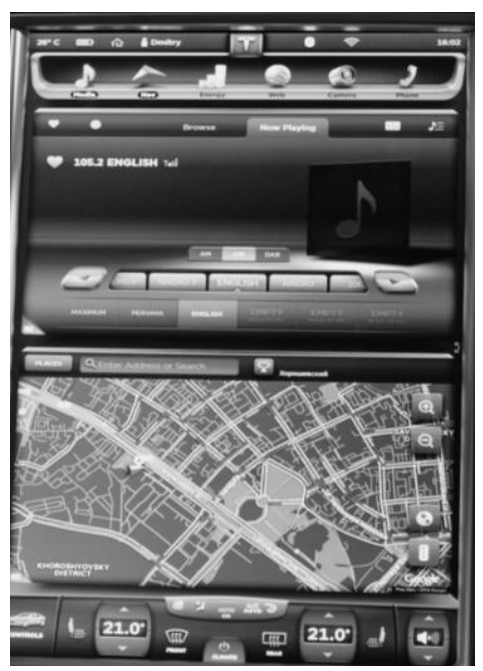

Fig. 4 - Application output of media player and navigation to the main display

As for programs the main menu is divided into the following tabs categories:

- media player;

- maps and navigation;

- calendar;

- control and adjustment of power consumption;

- web browser;

- rear view camera;

- telephone.

Table 3 - Technical specifications of Tesla Model X

\begin{tabular}{|c|c|c|c|}
\hline Automobile & \multicolumn{3}{|c|}{ Tesla Model X } \\
\hline Modification type & $70 \mathrm{D}$ & 90D & P90D \\
\hline Body type & \multicolumn{3}{|c|}{ universal } \\
\hline Number of seats & $5(6,7)$ & $5(6,7)$ & $5(6,7)$ \\
\hline Length, mm & \multicolumn{3}{|c|}{5004} \\
\hline Width, mm & \multicolumn{3}{|c|}{2083} \\
\hline Height, mm & \multicolumn{3}{|c|}{1626} \\
\hline Wheel-base, mm & \multicolumn{3}{|c|}{3061} \\
\hline Kurb weight, kg (ibs) & $2391(5271)$ & $2391(5271)$ & $2441(5381)$ \\
\hline Front electric traction motor & \multicolumn{3}{|c|}{ 3-phase, 4-pole asynchronous AC motor with copper rotor } \\
\hline Location & \multicolumn{3}{|c|}{ Transverse, above the front axle } \\
\hline
\end{tabular}




\begin{tabular}{|c|c|c|c|}
\hline Maximum power. hp. $(\mathrm{kW})$ & $150(110,5)$ & $259(191)$ & $259(191)$ \\
\hline Rear electric traction motor & \multicolumn{3}{|c|}{ 3-phase, 4-pole asynchronous AC motor with copper rotor } \\
\hline Location & \multicolumn{3}{|c|}{ Transverse, behind the rear axle } \\
\hline Maximum power, $\mathrm{hp} .(\mathrm{kW})$ & $300(221)$ & 259 (191) & $503(370,5)$ \\
\hline $\begin{array}{l}\text { Aggregate capacity of power unit, hp } \\
(\mathrm{kW}) \mathrm{rpm}\end{array}$ & $450(331,5) /-$ & $518(382) / 900-8600$ & $762(561,5) / 900-8600$ \\
\hline Total torque, $\mathrm{Nm}$ & 525 & 930 & 965 \\
\hline Traction battery accumulator (TBA) & $\begin{array}{l}\text { Lithium ion battery, } \\
\text { capacity } 70 \mathrm{~kW} \cdot \mathrm{h}\end{array}$ & $\begin{array}{l}\text { Lithium ion battery, } \\
\text { capacity } 90 \mathrm{~kW} \cdot \mathrm{h}\end{array}$ & $\begin{array}{l}\text { Lithium ion battery, } \\
\text { capacity } 90 \mathrm{~kW} \cdot \mathrm{h}\end{array}$ \\
\hline Drive gear & \multicolumn{3}{|c|}{ permanent all-wheel drive } \\
\hline Drive train & \multicolumn{3}{|c|}{$\begin{array}{l}\text { Single stage gear boxes in the front/rear axles drive; automatic } \\
\text { transmission }\end{array}$} \\
\hline Tires & \multicolumn{3}{|c|}{ 265/45 R20 - 275/45 R21 } \\
\hline Top speed, km/h & $225^{*}$ & $249^{*}$ & $250^{*}$ \\
\hline Acceleration time $0-100 \mathrm{~km} / \mathrm{h}, \mathrm{c}$ & 6,0 & 4,8 & $3,8(3,2)$ \\
\hline $\begin{array}{l}\text { Maximum range, km (driving cycle } \\
\text { NEDC) }\end{array}$ & 354 & 414 & 402 \\
\hline Remark & \multicolumn{3}{|c|}{ * Limitation of electronics } \\
\hline
\end{tabular}

Above bookmarking there are icons of quick access to some additional functions: a profile of the driver, car parameters settings (automatic doors lock, mirrors fine-tuning, climate control, lighting, the screen itself and directly the car software), software updates, Bluetooth, Wi- Fi and passenger airbags deactivation.

Mechanical components include only turn signal switches and wind-screen wipers, forward-reverse drive handle and two pedals: gas (accelerator) and brakes.

Instead of a mechanical instrument panel, display of a smaller size with resolution $1280 \mathrm{~h} 480$ is used. It displays all necessary for the driver information (current vehicle status): speed, power consumption, range, distance travelled by the car, ambient temperature. During battery charging the dashboard indicates voltage and current strength (Fig. 5). When driving, instead of graphical icons the display shows speedometer, economizer, and other more conventional instruments - everything what the driver might require. By pressing one of the buttons on the steering wheel, on the right part of display, there appears a menu of several frequently requested functions:

- climate settings for a driver's seat;

- fan blower speed;

- brightness of the driver's screen;

- hatch control (the opening level is measured in percentage);

- switchover for the media source.

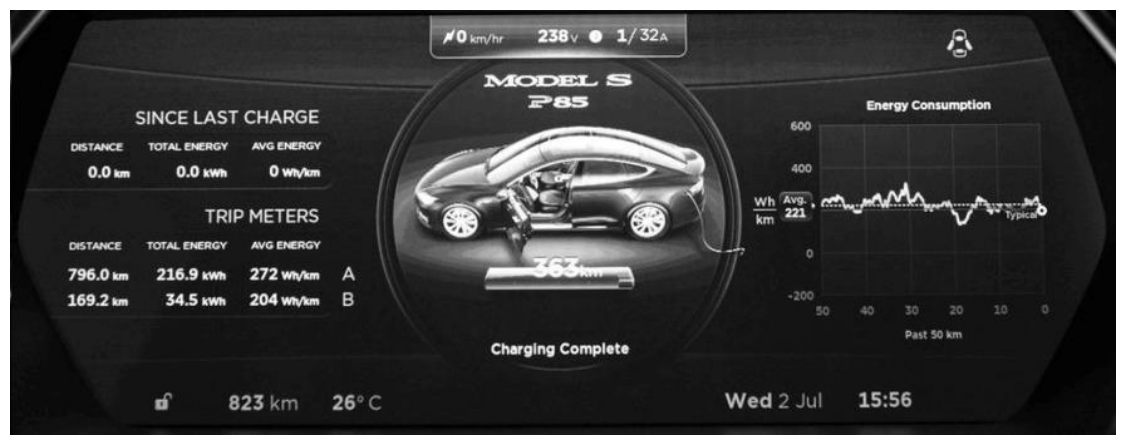

Fig. 5 - Appearance of the status panel at the time of charging

Control of all systems through a single computer module allows the manufacturer in the remote access mode (Wi-Fi or $3 \mathrm{G}$ ), updating software, to improve the tactical and technical characteristics of the vehicle (to increase by $6 \%$ the battery power, top speed and acceleration speed, to obtain the function of self-driving ...), to perform basic diagnostics of its main components, and eliminate minor faults. Thus, the manufacturer retains detailed statistics data for each battery use, information 
on charge-discharge, charge flow, any shortcomings and can predict battery behavior for many years to come. The operating system automatically collects data about the vehicle operation in each "abnormal situation" and sends it to the company server, thus improving the autopilot function, which becomes "smarter" with each algorithm update [14, 16].

Modern electric vehicles are not less powerful than vehicles with combustion engines both in speed and acceleration amount. Year by year, the top range of the vehicle increases and the recharging battery time decreases.

Tesla Motors company has created the Supercharger charging station, which allows to charge $85 \mathrm{~kW} \cdot \mathrm{h}$ battery of electric vehicle by $50 \%$, is 20 minutes, in 40 minut - by $80 \%$, in 1.5 hours - full charge of the battery, and to replace the battery with a fully charged one in 1.5 minutes. This record speed of charge became possible due to the power of the charging station of 120 $\mathrm{kW}$ and power supply directly to the battery instead of the traditional charging scheme. At this time no load occurs on the power grid through the use of alternative energy sources - solar cells at the charging stations [16].

The battery performance and electric power, and hence its range is still affected by the ambient temperature (at $-10{ }^{\circ} \mathrm{C}$ with an average snow drift level the Tesla power falls by $20 \%$ ), but isn't critical for the electric vehicle with the range of 500 $\mathrm{km}$ anymore. Especially since the regenerative braking system, being constantly fed by the battery accumulator, when driving, makes virtually impossible the complete battery discharge.

Due to removal of gas tank, all flammable liquids, and related to them components, electric vehicles are safer than vehicles with internal combustion engines. Experts of the Tesla Motors company has created an electric vehicle, which became one of the few means of transport, that received a maximum overall rating of "5 stars" by the standards of EuroNCAP (European New Car Assessment Program) and the NHTSA (National Highway Traffic Safety Administration) in all types of crash tests ( the best safety record in 2013). It was provided due to the availability of [23]:

- a heavy flat battery located at the bottom, made of heavy-duty material, providing additional stability and control;

- System of battery power-off in an emergency;

- steel reinforced and therefore durable aluminum housing;

- a small size motor located on the rear axle, whereby the crumple zone increases threefold;

- 8 airbags;

- additional anti-lock braking system ABS;

- seat belts;

- immobilizer;

- isolation of the vehicle control system of information and entertainment one;

- position sensors of driver and passenger seat, adjusting the operation of security systems in the optimal way...

The introduction of electric cars in our lives has become an urgent task in the light of the new agreement, worked out on the basis of the Climate Change Conference in Paris (December 2015) and endorsed by 196 of its participants, that actually binds the humanity to get away from fossil energy and develop technologies of obtaining and using energy from in-renewable sources.

This serious attitude to environmental issues contributes to the development of the car market with electric motors, which largely depends on the availability of infrastructure, price and public policy. In Ukraine, the joint project of OKKO charging network owners and Tesla Club Ukraine has become the most large scale project on creation of 34 free charging terminals for electric vehicles in 2014 on the busiest country highways. Tesla Motors plans to open two Supercharger stations of fast charging in Kiev and Lvov regions in 2016.

Unfortunately, the economy state of the country does not allow introducing incentives and compensation to owners of electric vehicles like in the developed European countries (Norway, Denmark, the Netherlands, Germany, France ...) and the United States. Nevertheless, the government abolished import duty for vehicles with electric motors, which reduced its price by $12 \%$ in November of last year. At present the law project on removal of VAT on the purchase of an electric vehicle is submitted to the Parliament, the adoption of which will reduce the price to $40 \%$.

Having regard to the above and to the policy of Tesla Motors Company on creation of a low-cost vehicle, which presentation (Tesla Model 3) has to be held already in March, the increasing popularity and demand for Tesla brand electric cars in all the major cities around the world and in Ukraine is inevitable.

\section{Referenses}

[1] Khegay Y.A. Environmental issues in the sphere of motor transport in the Russian federation // Theory and practices of social development. - 2014. - № 2. - P. 386-388;

[2] Khegay Y.A., Tarasova N. O., Lukyanenko E. S. Development prospects of electric and hybrid vehicles // Theory and practices of social development. - 2014. - № 20. - P. 76-78;

[3] Rusakova T. I. Research of air pollution from traffic in «street canyons» of city // Science and Transport Progress. Bulletin of Dnepropetrovsk National University of Railway Transport. Series «Ecology on transport». - 2015. - № 1 (55). - P. 23-34. - DOI: 10.15802/STP2015/38236;

[4] Zotov L.L. Environmental safety of vehicles: training manual или tutorial. - St. Petersburg, - 2005, - 115 р.;

[5] Kuharev A.M., Evdokimov M.V. Vehicle as a source of electromagnetic hazard // Technical and technological problems of service. - 2014. - № 2 (28). - P. 91- 94; 
[6] Selivanov S. E., Filenko V.V., Bazhynov A.V., Budianskaya E.N. Electromagnetic biosphere pollution by motor transport (vehicles, electric vehicles, hybrid vehicles) // Motors transport. - 2009. - № 25;

[7] Daniels D. Modern automotive technology: the textbook. - Moscow, - 2003, - 224 p.;

[8] Znaemskiy S. News. The world sale results of Electric vehicles are announced [Electronic resource]. // Autoreview. 2015.- Access to the resource: http://www.autoreview.ru/;

[9] Tesla Motors: 5 things, automobile manufacturers need to learn [Electronic resource]. - 2013. - Access to the resource: http://ukrday.com/avto/novosti.php?id=102634;

[10] Technical director of company Tesla Motors about what's going on in the company "under the hood" [Electronic resource]. - 2014. - Internet-resource of company LTD. «AEnergy». - Access to the resource: http://aenergy.ru/4324;

[11] Drace Baer The Making Of Tesla: Invention, Betrayal, And The Birth Of The Roadster [Electronic resource] // Business Iinsider. - 2014. Access to the resource: http://www.businessinsider.com/tesla-the-origin-story-2014-10;

[12] Tesla Motors - history of company [Electronic resource]. - 2014. - Access to the resource: http://shoptesla.ru/articles/tesla-motors history company/;

[13] Electric Vehicle Tesla Roadster [Electronic resource] // MOTORbreath. - Access to the resource: http://motorbreath.ru;

[14] World of Electric vehicles [Electronic resource]. - Access URL: http://tesla-mobil.ru/category/tesla-model/;

[15] Tesla Roadster: "the first-born child" of Electric vehicles manufacturer [Electronic resource]. - 2014. - Access to the resource: http://www.allcarz.ru/catalog/tesla/;

[16] Tesla Motors|Premium Electric Vehicles [Official site of company Tesla Motors]. - Access to the resource: https://www.teslamotors.com/;

[17] Guriyanov V. Verification on roads. Kilowatts and quietness // Autoreview. - 2014. - № 5 (537). - P. 22-28;

[18] Znaemskiy S. Verification on roads. Acceleration. // Autoreview. - 2015. - № 12 (567). - P. 26-31;

[19] Tesla Model S (01.2012-) - technical characteristics and trim levels [Electronic resource]. - Access to the resource: http://www.drom.ru/catalog/tesla/model_s/g_2012_3581/;

[20] Kalashnikov S. All interesting facts about Tesla Model X, well-known today [Electronic resource] // Moscow Tesla Club.- 2016. - Access to the resource: http://teslamodelx.ru/obzor-tesla;

[21] Test-drive: premiere Tesla Model X: Technological wonder // Test-drive. - 2015. - № 11. - C. 12-17;

[22] In one "Falkone". Tesla Model X: open-up doors and $90 \mathrm{~kW} \cdot \mathrm{h}$ battery //Autoreview. - 2015. - № 19 (573).- P.2;

[23] Solovjov S. Tesla: five reasons to admire and to fear [Electronic resource]. - Access URL: http://www.executive.ru/management/marketing/1979975-tesla-pyat-prichin-voshischatsya-i-opasatsya/;

[24] Those which are not available: How to increase the sales of electric vehicles in Ukraine [Electronic resource] // Delo. 2015. - Access URL: http://delo.ua/auto/. 